\title{
IMPLEMENTASI PENGAJARAN CARA MENYIKAT GIGI MENGGUNAKAN METODE DRILL DALAM MENUNJANG PELATIHAN KADER KESEHATAN GIGI DAN MULUT DI MASYARAKAT
}

\author{
${ }^{1}$ Aan Kusmana, ${ }^{1}$ Muhammad Fiqih Sabilillah \\ ${ }^{1}$ Jurusan Keperawatan Gigi Poltekkes Kemenkes Tasikmalaya, Indonesia
}

sabilillah.fiqih@gmail.com

Diterima: 30 Oktober 2018

Direvisi: 17 Desember 2018

Diterbitkan:07 Januari 2019

\begin{abstract}
Drill method is a way of teaching by giving exercises to what the target has learned so as to obtain a certain skill. The word exercise means that something is always repeated, but somehow between the first learning situation and a real learning situation, he will try to practice his skills. It should be noted that the training is not given to the target without understanding, so the exercise is preceded by a basic understanding. The right method greatly helps the business achievement of changing the target behavior. The goal of community service "Implementation of Teaching Teeth Brushing Using Drill Methods in Supporting Training of Dental and Oral Health Cadres in the Community" totaled 30 people. The method of implementation is by transferring knowledge about dental and oral health through lectures and question and answer then teaching them how to brush teeth through demonstrations and simulations. Knowledge before and after being given intervention about the teaching of brushing teeth in the Al-Ikhlas Study Group DKM Babakan Jati Kel. Mulyasari Kec. Tamansari Kota Tasikmalaya obtained an increase in knowledge with criteria of less than $60 \%$. The status of dental and oral hygiene before and after being given an intervention about the teaching of brushing teeth in the Al-Ikhlas Study Group DKM Babakan Jati Kel. Mulyasari Kec. Tamansari City of Tasikmalaya obtained an increase in dental and oral hygiene status with a bad criterion of $63.33 \%$.
\end{abstract}

Keyword $\quad$ : Tooth Brushing, Drill Method, Cadre Training

\begin{abstract}
ABSTRAK
Metode drill merupakan suatu cara mengajar dengan memberikan latihan-latihan terhadap apa yang telah dipelajari sasaran sehingga memperoleh suatu keterampilan tertentu. Kata latihan mengandung arti bahwa sesuatu itu selalu diulang-ulang, akan tetapi bagaimanapun juga antara situasi belajar yang pertama dengan situasi belajar yang realistis, ia akan berusaha melatih keterampilannya. Perlu diperhatikan latihan itu tidak diberikan begitu saja kepada sasaran tanpa pengertian, jadi latihan itu didahului dengan pengertian dasar. Metode yang tepat sangat membantu pencapaian usaha mengubah perilaku sasaran. Sasaran pada pengabdian kepada masyarakat "Implementasi Pengajaran Cara Menyikat Gigi Menggunakan Metode Drill dalam Menunjang Pelatihan Kader Kesehatan Gigi dan Mulut di Masyarakat" berjumlah 30 orang. Metode pelaksanaan yaitu dengan mentransfer ilmu pengetahuan tentang kesehatan gigi dan mulut melalui ceramah dan tanya jawab selanjutnya melakukan pengajaran cara menyikat gigi melalui demonstrasi dan simulasi. Pengetahuan sebelum dan sesudah diberikan intervensi tentang pengajaran cara menyikat gigi pada Kelompok Pengajian AlIkhlas DKM Babakan Jati Kel. Mulyasari Kec. Tamansari Kota Tasikmalaya didapatkan peningkatan pengetahuan dengan kriteria kurang sebanyak $60 \%$. Status kebersihan gigi dan mulut sebelum dan sesudah diberikan intervensi tentang pengajaran cara menyikat gigi pada Kelompok Pengajian AlIkhlas DKM Babakan Jati Kel. Mulyasari Kec. Tamansari Kota Tasikmalaya didapatkan peningkatan status kebersihan gigi dan mulut dengan kriteria buruk sebanyak 63,33\%.
\end{abstract}

Kata kunci : Menyikat Gigi, Metode Drill, Pelatihan Kader 


\section{PENDAHULUAN}

Pembangunan kesehatan bertujuan untuk meningkatkan kesadaran, kemauan dan kemampuan hidup sehat bagi setiap orang agar terwujud derajat kesehatan masyarakat yang setinggi-tingginya, sebagai investasi bagi pembangunan sumber daya manusia yang produktif secara sosial dan ekonomi. Indicator Oral Health Global Goal menurut WHO tentang status kesehatan gigi dan mulut penduduk Indonesia adalah memelihara kesehatan gigi dan mulut dari anak, remaja, dewasa hingga lansia. Selain itu, target kementrian kesehatan untuk menjadikan setiap anak bebas dari karies dan mampu memelihara kesehatan gigi dan mulutnya adalah $90 \%$.

Riset kesehatan dasar (Riskesdas) menunjukan perilaku penduduk umur 10 tahun ke atas yang berkaitan dengan kebiasaan menyikat gigi dan kapan waktu menyikat gigi dilakukan. Sebagian besar penduduk umur 10 tahun ke atas $(91,1 \%)$ mempunyai kebiasaan menyikat gigi setiap hari. Hasil optimal dalam menyikat gigi yang benar didapat dengan menyikat gigi setiap hari pada waktu pagi hari sesudah sarapan dan malam sebelum tidur. Pada umumnya masyarakat $(90,7 \%)$ menyikat gigi setiap hari pada waktu mandi pagi dan atau sore. Proporsi masyarakat yang menyikat gigi setiap hari sesudah makan pagi hanya $12,6 \%$ dan sebelum tidur malam hanya $28,7 \%{ }^{2,11}$.

Prevalensi nasional menyikat gigi setiap hari adalah 94,2\% sebanyak 15 provinsi berada dibawah prevalensi nasional. Perilaku yang benar dalam menyikat gigi berkaitan dengan faktor gender, ekonomi dan daerah tempat tinggal ternyata ditemukan sebagian besar penduduk Indonesia menyikat gigi pada saat mandi pagi maupun mandi sore sebanyak (76,6\%). Masyarakat yang menyikat gigi dengan benar adalah setelah makan pagi dan sebelum tidur malam, untuk Indonesia ditemukan hanya 2,3\% $\%^{3,12}$.

Perubahan perilaku ke arah yang lebih baik hanya dapat dilakukan melalui proses yang disengaja dengan grand design yang mencakup proses ${ }^{4,13}$. Metode atau cara yang digunakan untuk mengimplementasikan grand design (rencana) yang sudah disusun dapat tercapai secara optimal apabila metode yang digunakan untuk merealisasikan strategi tersebut tepat. Keberhasilan implementasi strategi pembelajaran sangat tergantung pada cara seseorang menggunakan metode pembelajaran, karena suatu strategi pembelajaran hanya mungkin dapat diimplementasikan melalui penggunaan metode pembelajaran.

Pembelajaran merupakan suatu metode atau cara mengubah perilaku dengan domain pengetahuan dan sikap sehingga pada akhirnya seseorang dapat melakukan tindakan perubahan dengan benar. Beberapa metode pembelajaran yang digunakan untuk mengimplementasikan strategi pembelajaran adalah diantaranya metode ceramah, metode demonstrasi, metode diskusi dan metode simulasi ${ }^{5}$. Dalam proses penyampaian materi pembelajaran kepada sasaran pemilihan metode yang tepat sangat membantu pencapaian usaha mengubah tingkah laku sasaran yaitu menggunakan metode drill ${ }^{6}$.

Metode drill adalah suatu cara mengajar dengan memberikan latihan-latihan terhadap apa yang telah dipelajari sasaran sehingga memperoleh suatu keterampilan tertentu. Kata latihan mengandung arti bahwa sesuatu itu selalu diulang-ulang, akan tetapi bagaimanapun juga antara situasi belajar yang pertama dengan situasi belajar yang realistis, ia akan berusaha melatih keterampilannya. Bila situasi belajar itu diubah-ubah kondisinya sehingga menuntut respons yang berubah, maka keterampilan akan lebih disempurnakan. Ada keterampilan yang dapat disempurnakan dalam jangka waktu yang pendek dan ada yang membutuhkan waktu cukup lama. Perlu diperhatikan latihan itu tidak diberikan begitu saja kepada sasaran tanpa pengertian, jadi latihan itu didahului dengan pengertian dasar. Metode yang tepat sangat membantu pencapaian usaha mengubah perilaku sasaran. Menurut Notoatmojo perubahan perilaku baru/ adopsi perilaku yang didasari oleh pengetahuan akan bersifat langgeng (long 
lasting), sebaliknya perilaku yang tidak didasarkan oleh pengetahuan dan kesadaran tidak akan berlangsung lama ${ }^{7,8,9}$.

\section{METODE}

Sasaran pada pengabdian kepada masyarakat "Implementasi Pengajaran Cara Menyikat Gigi Menggunakan Metode Drill dalam Menunjang Pelatihan Kader Kesehatan Gigi dan Mulut di Masyarakat" berjumlah 30 orang. Metode pelaksanaan pada pengabdian kepada masyarakat "Implementasi Pengajaran Cara Menyikat Gigi Menggunakan Metode Drill dalam Menunjang Pelatihan Kader Kesehatan Gigi dan Mulut di Masyarakat" adalah dengan mentransfer ilmu pengetahuan tentang kesehatan gigi dan mulut melalui ceramah dan tanya jawab selanjutnya melakukan pengajaran cara menyikat gigi melalui demonstrasi dan simulasi.

Persiapan kegiatan pengabdian kepada masyarakat "Implementasi Pengajaran Cara Menyikat Gigi Menggunakan Metode Drill dalam Menunjang Pelatihan Kader Kesehatan Gigi dan Mulut di Masyarakat" adalah sebagai berikut:

1. Survei tempat pelaksanaan pada Kelompok Pengajian Al-Ikhlas DKM Babakan Jati Kel. Mulyasari Kec. Tamansari Kota Tasikmalaya.

2. Pembuatan proposal pengabdian kepada masyarakat "Implementasi Pengajaran Cara Menyikat Gigi Menggunakan Metode Drill dalam Menunjang Pelatihan Kader Kesehatan Gigi dan Mulut di Masyarakat".

3. Penyelesaian admnistrasi perizinan lokasi pengabdian kepada masyarakat "Implementasi Pengajaran Cara Menyikat Gigi Menggunakan Metode Drill dalam Menunjang Pelatihan Kader Kesehatan Gigi dan Mulut di Masyarakat".

4. Menyusun materi pengajaran cara menyikat gigi.

5. Menyiapkan leaflet pengajaran cara menyikat gigi.

6. Melakukan sosialisasi progam pengabdian kepada masyarakat pada Kelompok Pengajian Al-Ikhlas DKM Babakan Jati Kel. Mulyasari Kec. Tamansari Kota Tasikmalaya.

7. Menyiapkan alat dan bahan program pengabdian kepada masyarakat "Implementasi Pengajaran Cara Menyikat Gigi Menggunakan Metode Drill dalam Menunjang Pelatihan Kader Kesehatan Gigi dan Mulut di Masyarakat" pada pada Kelompok Pengajian AlIkhlas DKM Babakan Jati Kel. Mulyasari Kec. Tamansari Kota Tasikmalaya.

Adapun kegiatan pengabdian kepada masyarakat ini dilakukan setelah semua tahap persiapan diselesaikan. Kelompok Pengajian Al-Ikhlas DKM Babakan Jati Kel. Mulyasari Kec. Tamansari Kota Tasikmalaya akan diberi pengetahuan tentang kesehatan gigi dan mulut melalui ceramah dan tanya jawab selanjutnya melakukan pengajaran cara menyikat gigi melalui demonstrasi dan simulasi.

Selanjutnya dilakukan evaluasi. Evaluasi kegiatan pengabdian kepada masyarakat ini adalah untuk mengetahui keberhasilan kegiatan, melalui pretest dan posttest pengetahuan tentang kesehatan gigi dan melalukan pemeriksaan OHI-S sebagai indikatornya pada Kelompok Pengajian Al-Ikhlas DKM Babakan Jati Kel. Mulyasari Kec. Tamansari Kota Tasikmalaya.

\section{HASIL DAN PEMBAHASAN}

Distribusi frekuensi berdasarkan jenis kelamin pada Kelompok Pengajian Al-Ikhlas DKM Babakan Jati Kel. Mulyasari Kec. Tamansari Kota Tasikmalaya adalah sebagai berikut:

Tabel 1. Distribusi Frekuensi berdasarkan Jenis Kelamin

\begin{tabular}{clcc}
\hline No. & Jenis Kelamin & Jumlah & Presentase \\
\hline 1 & Laki-Laki & 4 & $13,33 \%$ \\
\hline 2 & Perempuan & 26 & $86,67 \%$ \\
\hline \multicolumn{2}{c}{ Jumlah } & 30 & $100 \%$ \\
\hline
\end{tabular}


Pengabdian kepada masyarakat "Implementasi Pengajaran Cara Menyikat Gigi Menggunakan Metode Drill dalam Menunjang Pelatihan Kader Kesehatan Gigi dan Mulut di Masyarakat" dengan sasaran Kelompok Pengajian Al-Ikhlas DKM Babakan Jati Kel. Mulyasari Kec. Tamansari Kota Tasikmalaya terdiri dari perempuan sebanyak 26 orang $(86,67 \%)$ dan laki-laki sebanyak 4 orang $(13,33 \%)$.

Distribusi frekuensi berdasarkan pengetahuan sebelum diberikan intervensi tentang pengajaran cara menyikat gigi pada Kelompok Pengajian Al-Ikhlas DKM Babakan Jati Kel. Mulyasari Kec. Tamansari Kota Tasikmalaya adalah sebagai berikut:

Tabel 2. Distribusi Frekuensi berdasarkan Pengetahuan sebelum diberikan Intervensi tentang Pengajaran Cara Menyikat Gigi

\begin{tabular}{clcc}
\hline No. & Pengetahuan & Jumlah & Presentase \\
\hline 1 & Baik (11-15) & 0 & $0 \%$ \\
\hline 2 & Sedang (6-10) & 7 & $23,33 \%$ \\
\hline 3 & Kurang (0-5) & 23 & $76,67 \%$ \\
\hline & Jumlah & 30 & $100 \%$ \\
\hline
\end{tabular}

Tabel diatas menunjukkan pengetahuan sebelum diberikan intervensi tentang pengajaran cara menyikat gigi pada Kelompok Pengajian Al-Ikhlas DKM Babakan Jati Kel. Mulyasari Kec. Tamansari Kota Tasikmalaya yaitu tidak ada dengan kriteria baik, 7 orang $(23,33 \%)$ dengan kriteria sedang dan 23 orang $(76,67 \%)$ dengan kriteria kurang.

Distribusi frekuensi berdasarkan pengetahuan sesudah diberikan intervensi tentang pengajaran cara menyikat gigi pada Kelompok Pengajian Al-Ikhlas DKM Babakan Jati Kel. Mulyasari Kec. Tamansari Kota Tasikmalaya adalah sebagai berikut:

Tabel 3. Distribusi Frekuensi berdasarkan Pengetahuan sesudah diberikan Intervensi tentang Pengajaran Cara Menyikat Gigi

\begin{tabular}{clcc}
\hline No. & Pengetahuan & Jumlah & Presentase \\
\hline 1 & Baik (11-15) & 12 & $40 \%$ \\
\hline 2 & Sedang (6-10) & 13 & $43,33 \%$ \\
\hline 3 & Kurang (0-5) & 5 & $16,67 \%$ \\
\hline & Jumlah & 30 & $100 \%$ \\
\hline
\end{tabular}

Tabel diatas menunjukkan pengetahuan sesudah diberikan intervensi tentang pengajaran cara menyikat gigi pada Kelompok Pengajian Al-Ikhlas DKM Babakan Jati Kel. Mulyasari Kec. Tamansari Kota Tasikmalaya yaitu 12 orang (40\%) dengan kriteria baik, 13 orang $(43,33 \%)$ dengan kriteria sedang dan 5 orang $(16,67 \%)$ dengan kriteria kurang.

Distribusi frekuensi berdasarkan pengetahuan sebelum dan sesudah diberikan intervensi tentang pengajaran cara menyikat gigi pada Kelompok Pengajian Al-Ikhlas DKM Babakan Jati Kel. Mulyasari Kec. Tamansari Kota Tasikmalaya adalah sebagai berikut:

Tabel 4. Distribusi Frekuensi berdasarkan Pengetahuan sebelum dan sesudah diberikan Intervensi tentang Pengajaran Cara Menyikat Gigi

\begin{tabular}{ccccccc}
\hline No. & Pengetahuan & $\begin{array}{c}\text { Pretest } \\
\text { (Sebelum) }\end{array}$ & $\%$ & $\begin{array}{c}\text { Posttest } \\
\text { (Sesudah) }\end{array}$ & $\%$ & $\begin{array}{c}\text { Peningkatan } \\
\text { Pengetahuan } \\
(\%)\end{array}$ \\
\hline 1 & Baik (11-15) & 0 & $0 \%$ & 12 & $40 \%$ & $40 \%$ \\
\hline 2 & Sedang (6-10) & 7 & $23,33 \%$ & 13 & $43,33 \%$ & $20 \%$ \\
\hline 3 & Kurang (0-5) & 23 & $76,67 \%$ & 5 & $16,67 \%$ & $60 \%$ \\
\hline & Jumlah & 30 & $100 \%$ & 30 & $100 \%$ & - \\
\hline
\end{tabular}

Tabel diatas menunjukkan pengetahuan sebelum dan sesudah diberikan intervensi tentang pengajaran cara menyikat gigi pada Kelompok Pengajian Al-Ikhlas DKM Babakan Jati Kel. Mulyasari Kec. Tamansari Kota Tasikmalaya didapatkan peningkatan pengetahuan dengan kriteria baik sebanyak 40\%, dengan kriteria sedang sebanyak $20 \%$ dan dengan kriteria kurang sebanyak $60 \%$.

Distribusi frekuensi berdasarkan status kebersihan gigi dan mulut sebelum diberikan intervensi tentang pengajaran cara menyikat gigi pada Kelompok Pengajian Al-Ikhlas DKM Babakan Jati Kel. Mulyasari Kec. Tamansari Kota Tasikmalaya adalah sebagai berikut: 
Tabel 5. Distribusi Frekuensi berdasarkan Status Kebersihan Gigi dan Mulut sebelum diberikan Intervensi tentang Pengajaran Cara Menyikat Gigi

\begin{tabular}{clcc}
\hline No. & Status Kebersihan Gigi dan Mulut & Jumlah & Presentase \\
\hline 1 & Baik $(0-1,2)$ & 0 & $0 \%$ \\
\hline 2 & Sedang $(1,3-3,0)$ & 11 & $36,67 \%$ \\
\hline 3 & Buruk $(3,1-6,0)$ & 19 & $63,33 \%$ \\
\hline & Jumlah & 30 & $100 \%$
\end{tabular}

Tabel diatas menunjukkan status kebersihan gigi dan mulut sebelum diberikan intervensi tentang pengajaran cara menyikat gigi pada Kelompok Pengajian Al-Ikhlas DKM Babakan Jati Kel. Mulyasari Kec. Tamansari Kota Tasikmalaya yaitu tidak ada dengan kriteria baik, 11 orang $(36,67 \%)$ dengan kriteria sedang dan 19 orang $(63,33 \%)$ dengan kriteria buruk.

Distribusi frekuensi berdasarkan status kebersihan gigi dan mulut sesudah diberikan intervensi tentang pengajaran cara menyikat gigi pada Kelompok Pengajian Al-Ikhlas DKM Babakan Jati Kel. Mulyasari Kec. Tamansari Kota Tasikmalaya adalah sebagai berikut:

Tabel 6. Distribusi Frekuensi berdasarkan Status Kebersihan Gigi dan Mulut sesudah diberikan Intervensi tentang Pengajaran Cara Menyikat Gigi

\begin{tabular}{clcc}
\hline No. & Status Kebersihan Gigi dan Mulut & Jumlah & Presentase \\
\hline 1 & Baik $(0-1,2)$ & 17 & $56,67 \%$ \\
\hline 2 & Sedang $(1,3-3,0)$ & 13 & $43,33 \%$ \\
\hline 3 & Buruk (3,1-6,0) & 0 & $0 \%$ \\
\hline & Jumlah & 30 & $100 \%$
\end{tabular}

Tabel diatas menunjukkan status kebersihan gigi dan mulut sesudah diberikan intervensi tentang pengajaran cara menyikat gigi pada Kelompok Pengajian Al-Ikhlas DKM Babakan Jati Kel. Mulyasari Kec. Tamansari Kota Tasikmalaya yaitu 17 orang $(56,67 \%)$ dengan kriteria baik, 13 orang $(43,33 \%)$ dengan kriteria sedang dan tidak ada dengan kriteria buruk.

Distribusi frekuensi berdasarkan status kebersihan gigi dan mulut sebelum dan sesudah diberikan intervensi tentang pengajaran cara menyikat gigi pada Kelompok Pengajian Al-Ikhlas DKM Babakan Jati Kel. Mulyasari Kec. Tamansari Kota Tasikmalaya adalah sebagai berikut:

Tabel 7. Distribusi Frekuensi berdasarkan Status Kebersihan Gigi dan Mulut sebelum dan sesudah diberikan Intervensi tentang Pengajaran Cara Menyikat Gigi

\begin{tabular}{ccccccc}
\hline No. & $\begin{array}{l}\text { Status Kebersihan } \\
\text { Gigi dan Mulut }\end{array}$ & $\begin{array}{c}\text { Pretest } \\
\text { (Sebelum) }\end{array}$ & $\%$ & $\begin{array}{c}\text { Posttest } \\
\text { Sesudah) }\end{array}$ & $\%$ & $\begin{array}{c}\text { Peningkatan } \\
\text { Pengetahuan } \\
(\%)\end{array}$ \\
\hline 1 & Baik $(0-1,2)$ & 0 & $0 \%$ & 17 & $56,67 \%$ & $56,67 \%$ \\
\hline 2 & Sedang $(1,3-3,0)$ & 11 & $36,67 \%$ & 13 & $43,33 \%$ & $6,66 \%$ \\
\hline 3 & Buruk $(3,1-6,0)$ & 19 & $63,33 \%$ & 0 & $0 \%$ & $63,33 \%$ \\
\hline & Jumlah & 30 & $100 \%$ & 30 & $100 \%$ & - \\
\hline
\end{tabular}

Tabel diatas menunjukkan status kebersihan gigi dan mulut sebelum dan sesudah diberikan intervensi tentang pengajaran cara menyikat gigi pada Kelompok Pengajian AlIkhlas DKM Babakan Jati Kel. Mulyasari Kec. Tamansari Kota Tasikmalaya didapatkan peningkatan status kebersihan gigi dan mulut dengan kriteria baik sebanyak 56,67\%, dengan kriteria sedang sebanyak 6,66\% dan dengan kriteria buruk sebanyak 63,33\%.

Hasil yang didapatkan pada pengabdian kepada masyarakat "Implementasi Pengajaran Cara Menyikat Gigi Menggunakan Metode Drill dalam Menunjang Pelatihan Kader Kesehatan Gigi dan Mulut di Masyarakat" dengan sasaran Kelompok Pengajian Al-Ikhlas DKM Babakan Jati Kel. Mulyasari Kec. Tamansari Kota Tasikmalaya adalah sebagai berikut:

1. Memahami tentang cara menyikat gigi yang baik dan benar.

2. Memahami tentang waktu menyikat gigi yang benar.

3. Menerapkan kebiasaan menyikat gigi setiap hari pada waktu setelah sarapan pagi dan sebelum tidur. 
6 | Aan Kusmana, Muhammad Fiqih Sabilillah

4. Meningkatkan pengetahuan tentang cara menyikat gigi dan mulut.

5. Meningkatkan kebersihan gigi dan mulut.

\section{SIMPULAN}

Berdasarkan pengabdian kepada masyarakat "Implementasi Pengajaran Cara Menyikat Gigi Menggunakan Metode Drill dalam Menunjang Pelatihan Kader Kesehatan Gigi dan Mulut di Masyarakat" dengan sasaran Kelompok Pengajian Al-Ikhlas DKM Babakan Jati Kel. Mulyasari Kec. Tamansari Kota Tasikmalaya dapat disimpulkan bahwa:

1. Pengetahuan sebelum dan sesudah diberikan intervensi tentang pengajaran cara menyikat gigi pada Kelompok Pengajian Al-Ikhlas DKM Babakan Jati Kel. Mulyasari Kec. Tamansari Kota Tasikmalaya didapatkan peningkatan pengetahuan dengan kriteria kurang sebanyak $60 \%$.

2. Status kebersihan gigi dan mulut sebelum dan sesudah diberikan intervensi tentang pengajaran cara menyikat gigi pada Kelompok Pengajian Al-Ikhlas DKM Babakan Jati Kel. Mulyasari Kec. Tamansari Kota Tasikmalaya didapatkan peningkatan status kebersihan gigi dan mulut dengan kriteria buruk sebanyak 63,33\%.

\section{DAFTAR PUSTAKA}

1. Sabilillah, M.F., 2015. Perbedaan antara Audiovideo dengan Demonstrasi Pantum terhadap Perilaku, Status Kebersihan Gigi \& Mulut Anak Slow Learner: Kajian terhadap Perilaku Pemeliharaan Kesehatan Gigi dan Mulut (Doctoral Dissertation, Program Pascasarjana UNDIP).

2. Riset Kesehatan Dasar (Risdeskas)., 2007. Riset Kesehatan Dasar Nasional 2007. Kementerian Kesehatan Republik Indonesia, Jakarta. Hal: 130.

3. -----.--., 2013. Riset Kesehatan Dasar Nasional 2013. Kementerian Kesehatan Republik Indonesia, Jakarta. Hal: 110-118.

4. Mubarak., 2011. Promosi Kesehatan untuk Kebidanan. Salemba Medika, Jakarta. Hal: 80-84.

5. Sanjaya, W., 2007. Strategi Pembelajaran Berorientasi Standar Proses Pendidikan. Kencana, Bandung. Hal: 293-299.

6. Herijulianti., dkk., 2002. Pendidikan Kesehatan Gigi. EGC, Jakarta. Hal: 63-66.

7. Notoatmodjo., 2003. Pendidikan dan Perilaku Kesehatan. Rineka Cipta, Jakarta. Hal: 15-49.

8. Kementerian Kesehatan., 2012. Buku Panduan Pelatihan Kader Kesehatan Gigi dan Mulut di Masyarakat. Direktorat Jenderal Bina Upaya Kesehatan, Jakarta. Hal: 1-4.

9. Poltekkes Kemenkes Tasikmalaya., 2016. Pedoman Pengabdian Masyarakat Tahun 2016. Unit Penelitian dan Pengabdian Masyarakat, Tasikmalaya. Hal: 272-290.

10.Sabilillah, M.F., Taftazani, R.Z., Sopianah, Y. and Fatmasari, D., 2016. Pengaruh Dental Braille Education (DBE) terhadap Oral Hygiene pada Anak Tunanetra. Jurnal Kesehatan Gigi, 3 (2), pp. 7-13.

11.Sabilillah, M.F. and Kristiani, A.K., 2017. Hubungan Oral Hygiene dengan Keterampilan Menggosok Gigi pada Anak Tunanetra. Actual Research Science Academic, 2(2), pp. 23-28.

12.Sopianah, Y., Sabilillah, M.F. and Oedijani, O., 2017. The Effects of Audio-Video Instruction in Brushing Teeth on the Knowledge and Attitude of Young Slow Learners in Cirebon Regency. Dental Journal (Majalah Kedokteran Gigi), 50(2), pp. 66-70.

13. Taftazani, R.Z., Sabilillah, M.F., Kartilah, T., Nugroho, C. and Miko, H., 2017. Effect of Dental Braille Education (DBE) on Oral Health Knowledge and Attitudes on Children with Visual Impairment. Jurnal Kesehatan Tasikmalaya, 1 (3). 